\title{
Hygienic Quality and Nutritional Value of Attiéké from Local and Imported Cassava Dough Produced with Different Traditional Starters in Burkina Faso
}

\author{
Guira Flibert1, Kabore Donatien2, Sawadogo-Lingani Hagrétou², Savadogo Aly1 \\ ${ }^{1}$ Laboratory of Applied Biochemistry and Immunology (LabIA), Department of Biochemistry-Microbiology, \\ Université Ouaga I Professor Joseph KI-ZERBO, Ouaga, Burkina Faso \\ 2Laboratory of Microbiology, Food Technology Department, IRSAT/CNRST), Ouagadougou, \\ Burkina Faso \\ Email: flibertguira@yahoo.fr, alysavadogo@gmail.com
}

Received 27 January 2016; accepted 13 June 2016; published 16 June 2016

Copyright $(\odot 2016$ by authors and Scientific Research Publishing Inc.

This work is licensed under the Creative Commons Attribution International License (CC BY).

http://creativecommons.org/licenses/by/4.0/

(c) (i) Open Access

\section{Abstract}

Attiéké is an essentially flavour starchy food produced from fermented cassava root. The product is widely consumed in Burkina Faso. The objective of the present study was to investigate the biochemical and the microbiological characteristics of attiéké from Burkina Faso. The samples (36) were collected from six (6) producers. Cassava dough which is used for attiéké production contains from $70.67 \% \pm 0.25 \%$ to $86.02 \% \pm 0.2 \%$ as starch. The undesirable organic elements rate is about $1.28 \% \pm 0.14 \%$ to $26.46 \% \pm 0.53 \%$. The inorganic impurities rate is about 0 to $7 \pm 0.1$ $\mathrm{mg} / 100 \mathrm{~g}$. Cassava dough acidity varies from $1.8 \pm 0.2$ to $12.4 \pm 0.1$; and its $\mathrm{pH}$ from $3.48 \pm 0.01$ to $4.20 \pm 0.01$. Lactic bacteria are the main microorganisms involved in cassava dough fermentation (5.17 to $9.30 \mathrm{log} \mathrm{cfu} / \mathrm{g}$ ). Yeasts and molds number is low ( $<6.53 \mathrm{log} \mathrm{cfu} / \mathrm{g}$ ). Attiéké moister is about $50.6 \% \pm 0.00 \%$ to $55.12 \% \pm 0.7 \%$ and its protein contents from 0.77 to $1.74 \pm 0.13 \mathrm{~g} / 100 \mathrm{~g}$. The content in lipid of attiéké shows an important variation and is about 0.15 to $3.28 \pm 0.32 \mathrm{~g} / 100 \mathrm{~g}$. Carbohydrates content varies from $36.6 \pm 0.04$ to $47.01 \pm 0.1 \mathrm{~g} / 100 \mathrm{~g}$ and its ashes content is from 140 to $780 \pm 20 \mathrm{mg} / 100 \mathrm{~g}$. Attiéké acidity and $\mathrm{pH}$ are less weak than cassava dough. They vary respectively from $0.92 \% \pm 0.05 \%$ to $4.08 \% \pm 0.57 \%$ and from 3.7 to $4.4 \pm 0.01$. As a main energizer food, attiéké energizing value is from 161.95 to $215.26 \mathrm{Kcal} / 100 \mathrm{~g}$. All the attiéké analyzed was exempt of aflatoxin $\left(B_{1}, B_{2}, G_{1}, G_{2}\right)$ and ochratoxin $A$. The local attiéké has higher acidity, fermented bacteria load, protein and minerals salt than the imported one. The process mastery is the mainly factor that determines nutritional and sanitary quality of attiéké. 


\section{Keywords}

\section{Attiéké, Inoculum, Hygienic Quality, Nutritional Value}

\section{Introduction}

Cassava (Manihot esculenta CRANTZ) is an important root crop in Africa, Asia, South America and India, providing energy for about 500 million people [1]. Traditionally, cassava roots are processed by different methods varying from region to region, leading to many different products like "gari", "tapioca", "placali" and "attiéké". Attiéké is an essentially flavour starchy food, produced from fermented cassava dough. Attiéké is widely consumed in Burkina Faso and its production is incoming generator activity especially for women [2]. To produce attiéké, cassava roots are peeled, cut into pieces, washed and grated. During grating, the cassava dough is mixed with a traditional prepared inoculum as starter culture called "magnan". The inoculum is prepared by storing boiled cassava roots for three days in a jute bag. As shown by Amoa-Awua et al. [3], the utilization of inoculum for attiéké production reduces significantly the fermentation time compared to other cassava fermented products, such as gari or chickwangue prepared without inocula [4] [5].

The inoculated dough is fermented overnight in covered container. After fermentation, the dough obtained is put into bags and pressed for several hours to remove water. The pressed cake is taken from the bags and squeezed through a sieve to obtain granules that are partially sun-dried. Fibers and waste are then removed. The granules are steamed to produce attiéké, which is sold in small plastic bags as a ready-to-eat food [5]. People in Burkina Faso enjoy it as a staple food, accompanied with salt, raw onions, spices, oil and fried fish.

The fermentation of cassava roots is very important because it helps to eliminate cyanides and to preserve, soften and produce important organic acids for the organoleptic properties of attiéké [6]-[8]. Several researchers have studied the "Attiéké" microflora [5]-[10], but the biochemical characteristics of cassava dough and attiéké produced in Burkina still remain insufficient. Therefore, the aim of the present study was to characterize cassava dough produced with four (4) different types of inocula used to ferment grated cassava into attiéké and to examine the nutritional quality of the final products (attiéké).

\section{Material and Methods}

\subsection{Sampling}

Four different types of traditional starter culture called inocula and coded A, B, C and D as described below (Table 1) were used by six (6) experienced traditional cassava processors in Burkina Faso to ferment cassava dough for attiéké processing. The cassava dough got from the four different types of cassava dough and the attiéké obtained were sampled in duplicate by using a sterile stomacher bags placed in icebox with ices and transported in the laboratory of microbiology of Food Technology Department (DTA/IRSAT/CNRST) for analysis.

In total, six (6) samples of imported cassava dough from Côte d'Ivoire, six (6) samples of cassava dough fermented with roasted inoculums, four (4) samples of cassava dough fermented with blanched inoculums and two (2) samples of cassava dough fermented with soaked inoculums were collected for microbiological analyses

Table 1. Characteristics of the inocula used for cassava dough production.

\begin{tabular}{cc}
\hline Cassava dough & Characteristics \\
\hline Roasted (Inoculum A) & $\begin{array}{r}\text { cassava tubers, were roasted on a subdued open fire for } 10 \text { min, wrapped } \\
\text { in a bag and left in a warm place for } 2 \text { days to ferment into inoculum }\end{array}$ \\
Blanched (Inoculum B) & $\begin{array}{r}\text { Small chunks of peeled cassava tubers, were blanched by boiling until Softening, } \\
\text { wrapped in a bag and placed in a warm place for } 2 \text { days to ferment into inoculum. }\end{array}$ \\
Soaked (Inoculum C) & $\begin{array}{r}\text { Small chunks of peeled cassava tubers, were soaked in water at ambient } \\
\text { temperature (30 }{ }^{\circ} \text { C) for } 7 \text { days; Then, they were sun dried }\end{array}$ \\
Imported cassava dough (Inoculum D) & Here, it an imported cassava dough Côte d'Ivoire. \\
\hline
\end{tabular}


as lactic acid bacteria, molds and yeasts numeration, impurities, starch, $\mathrm{pH}$ and total acidity. And 18 sam- ples of attiéké obtained from these fermented cassava dough were also collected for proximate compound determination of moisture, total carbohydrates, proteins, lipids, ash, energy value, minerals contents and mycotoxins (Aflatoxin $\mathrm{B}_{1}, \mathrm{~B}_{2}, \mathrm{G}_{1}, \mathrm{G}_{2}$ and ochratoxin A) analyses.

\subsection{Measurement of $\mathrm{pH}$ and Determination of Acidity}

Ten gram (10 g) of each sample were dissolved in $50 \mathrm{ml}$ of sterile peptoned buffered water and mixed. The $\mathrm{pH}$ was directly measured with a numeric pH-meter (WTW multi line P4). For Total acidity, $10 \mathrm{~g}$ of each sample are mixed with $50 \mathrm{ml}$ of distilled water in an erlenmeyer. $10 \mathrm{ml}$ of the dilution were then titrated against $0.1 \mathrm{~N}$ $\mathrm{KOH}$ using phenolphthalein as indicator; the total acidity was then calculated as a percentage of lactic acid.

\subsection{Enumeration of Lactic Acid Bacteria (LAB), Yeasts and Moulds}

The preparation of samples and tenfold dilutions for inoculation outs agar plates were carried out according to ISO-6887 [12]. For all numerations, $10 \mathrm{~g}$ of the samples were homogenized in a stomacher bags with $90 \mathrm{ml}$ of sterile peptoned buffered water. The Tenfold serials dilution was prepared and spread-plated for microorganisms count. Yeasts and Molds were cultivated on Sabouraud-Chloramphenicol Agar (Oxoid LTD, Basingstore, Hamsphire, England) after incubated at $25^{\circ} \mathrm{C}$ for 4 - 5 days and counted according to ISO 7954 standards [13]. Lactic acid bacteria were cultivated on De Man, Rogosa and Sharpe Agar (MRS, Merck 10660, Merck, Darmstadt, Germany) incubated anaerobically in an anaerobic conditions (anaerobic jar) at $37^{\circ} \mathrm{C}$, for $2-3$ days and counted according to ISO 15214 standards [14].

\subsection{Proximate Composition Determination}

Proximate analysis of samples was conducted using the following conventional procedures described by the Association of Official Analytical Chemists [15]. Dry matter was determinate by drying at $105^{\circ} \mathrm{C} \pm 2^{\circ} \mathrm{C}$ overnight; ash content by incineration at $550^{\circ} \mathrm{C}$ for $12 \mathrm{~h}$, crude protein $(\mathrm{N} \times 6.25)$ by the Kjeldahl method after acid digestion; and crude fat content by Soxhlet extraction using n-hexane. Total carbohydrate content was determined by the phenol sulphuric acid method according to Tollier and Robin [16] and the values were expressed in g/100 g of attiéké. The starch content was determined using the colorimetric method described by Jarvis and Walker [17]. The energy value was calculated using the method described by Merrill and Watt [18].

\subsection{Mineral Analysis}

The contents of the minerals (Ca, Mg, Fe, Zn, Na, K, P) were determined after digesting of $0.5 \mathrm{~g}$ of sample using the Atomic Absorption Spectrophotometric method as outlined in the Association of Official Analytical Chemists Approved method [15].

\subsection{Aflatoxin ( $\left.B_{1}, B_{2}, G_{1}, G_{2}\right)$ and Ochratoxin a Analyses Contents}

The analytical method used was based on liquid extraction with purification ( $5 \mathrm{~g}$ of sodium chloride $+125 \mathrm{ml}$ of methanol extraction solution), followed by analysis by high-performance liquid chromatography with fluorescence detector (HPLC/FLD) and a photochemical post-column reactor according to ISO 16050 [19].

\subsection{Organic Impurities}

For the determination of organic impurities $100 \mathrm{~g}$ of each sample were placed on a sieve (mesh=1.4 $\mathrm{mm}$ ) and drained with water. The retained residue was dried at $105^{\circ} \mathrm{C} \pm 2^{\circ} \mathrm{C}$ for about $10 \mathrm{~min}$ before weighing and expressed as the organic impurities.

\subsection{Inorganic Impurities}

For the determination of inorganic impurities, $100 \mathrm{~g}$ of each sample were shaken for $30 \mathrm{mn}$ in a beaker containing water. The sediment obtained was dried at $105^{\circ} \mathrm{C} \pm 2^{\circ} \mathrm{C}$ for 10 min before weighing and expressed as the inorganic impurities. 


\subsection{Statistical Analysis}

All the analyses were performed in triplicate. The data analysis was conducted using EXCELL and STATA version 2010. For physico-chemical and biochemical parameters, Simple Statistic Analysis was used to get means and standard deviations.

\section{Results}

\subsection{Chemical Properties and Microflora of the Cassava Dough Fermented with Different Types of Inocula}

\subsubsection{The Chemical Properties of the Fermented Cassava Dough}

1) Characteristics of the inocula used for cassava dough fermentation

The characteristics of the inocula used for the fermentation of the cassava dough are as showed in the following Table 1.

2) $\mathrm{pH}$ and acidity

Cassava sour dough has a $\mathrm{pH}$ ranged from 3.48 to 6.30 and its acidity is from $1.8 \%$ to $12.4 \%$ as lactic acid (Figure 1). Imported sour dough has a $\mathrm{pH}$ which varies from 3.56 to 4.2, and an acidity ranged from $1.8 \%$ to $9.6 \%$ some imported cassava sour dough considered as bad quality according to the processes are the least acidic (from $1.8 \%$ to $2.4 \%$ ). The sour dough fermented with soaked inoculum has a weak value of acidity ( $2.8 \%$ to $3.2 \%$ ) compared to those fermented with the blanched one (4.6\% to 6.5\%), Figure 1 . The fermented cassava dough from the roaster inoculum is the most acid (5.6\% to 6.3\%). The $\mathrm{pH}$ of these samples is more acid than that found by Sotomey [20] and Assanvo and al. [9].

3) Undesirable organic elements

The rate of undesirable organic elements varies from $1.2 \pm 0.14$ to $26.46 \pm 0.53 \mathrm{~g} / 100 \mathrm{~g}$ (Figure 1 and Figure 2). The organic impurities rate is relatively weak. It varies from 0 to $7 \mathrm{mg} / 100 \mathrm{~g}$ for local cassava dough and from 0 to $1 \mathrm{mg} / 100 \mathrm{~g}$ for the imported cassava dough.

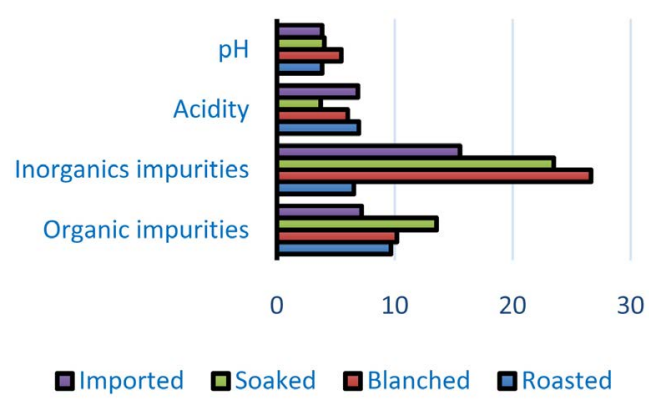

Figure 1. Properties of cassava dough according to the type of inoculum.

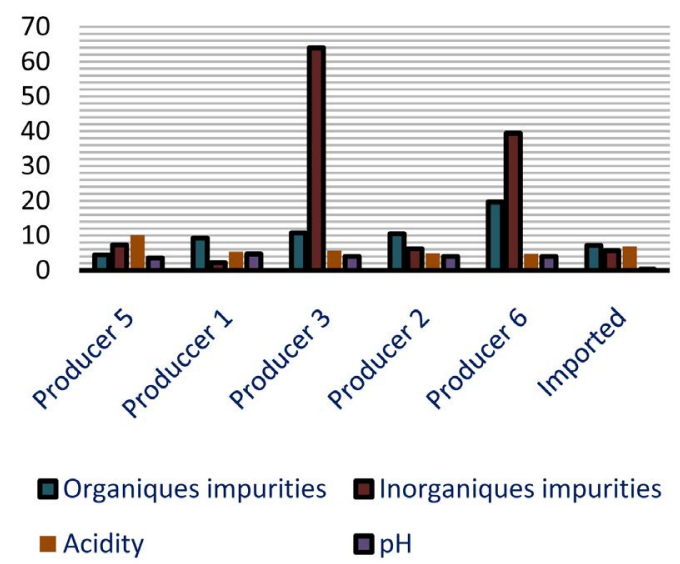

Figure 2. Physical properties of cassava dough according to producers. 
4) Undesirable inorganic elements

The results show a weak value of undesirable inorganic elements. It varies from 0 to $0.07 \%$ (Figure 1). The high value of inorganic elements is observed with Gaoua and some of Ouagadougou samples. The imported cassava dough has an undesirable inorganic rate varying from 0 to $0.01 \%$ (Figure 1 ).

\subsubsection{Microflora of the Cassava Sour Dough from Different Types of Inocula}

Lactic acid bacteria counts varied from 5.11 to $9.30 \mathrm{log}$ cfu/g. Except two samples (6.2 and $6.5 \mathrm{logcfu} / \mathrm{g}$ ), all the samples of local cassava fermented sour dough presented high values of lactic acid bacteria compared to the imported sour dough (Figure 3). Yeasts and molds showed maximal value, about $6.53 \mathrm{log} \mathrm{cfu} / \mathrm{g}$. whereas no yeast and mould was observed in four imported cassava fermented dough and two local cassava fermented dough.

\subsubsection{Starch Content of Cassava Fermented Dough}

The starch content in cassava dough varies from $68.57 \pm 1.23$ to $86.2 \pm 0.25 \mathrm{~g}$ for $100 \mathrm{~g}$ of dry matter (DM). For local cassava dough, the dried starter and the roasted starter have the weakest rates of starch $(68.57 \pm 1.23$ and $70.67 \pm 0.25)$.

\subsection{Properties of Attiéké Obtained from the Different Fermented Dough}

\subsubsection{Moister Content, $\mathrm{pH}$ and Acidity}

The moister content of attiéké varies from $50.19 \pm 0.00$ to $55.12 \% \pm 0.17 \%$ with an average of $52.92 \% \pm 1.62 \%$ (Figure 5). Then, the dry matter is about $44.88 \%$ to $49.81 \%$. This result is less than that found by Sotomey [20]. The attiéké lactic acidity varies from $0.92 \pm 0.05$ to $4.08 \% \pm 0.57 \%$ as lactic acid, and its $\mathrm{pH}$ from 3.7 to $4.5 \pm$ 0.01 (Figure 4)

\subsubsection{Macronutrients (Total Carbohydrates, Fat, Protein, Ashes) Content and Energy Value} The total carbohydrate content in attiéké varies from $80.35 \pm 0.87$ to $97.62 \pm 0.01 \mathrm{~g} / 100 \mathrm{~g}$ (Figure 5) according

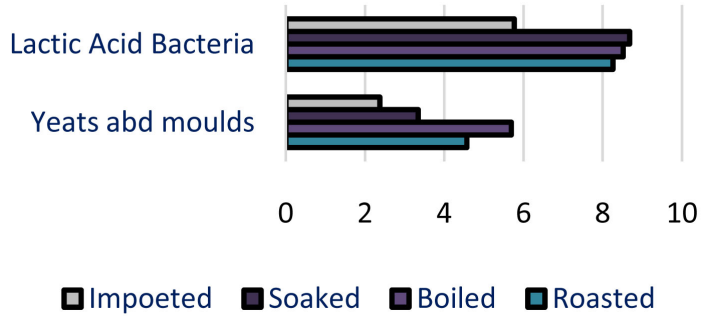

Figure 3. Lactic acid bacteria, yeasts and moulds (log cfu/g) in cassava dough according to the fermentation technology.

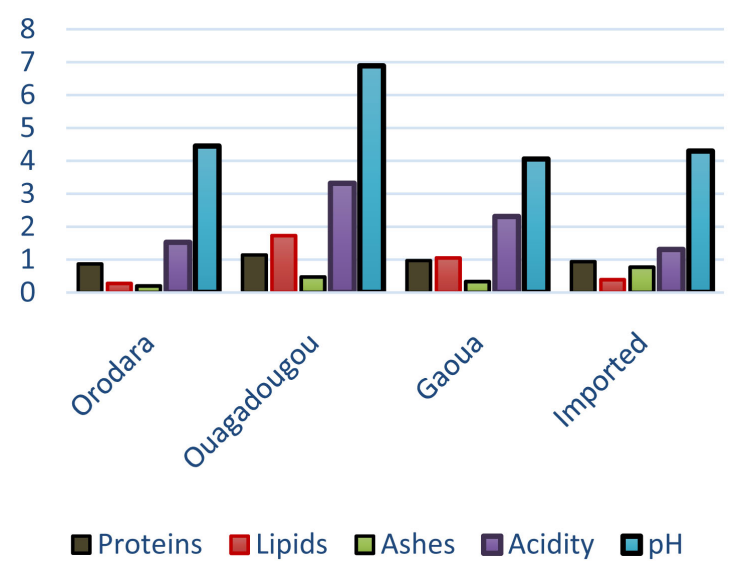

Figure 4. Biochemical values (g/100g) of attiéké according to localities. 


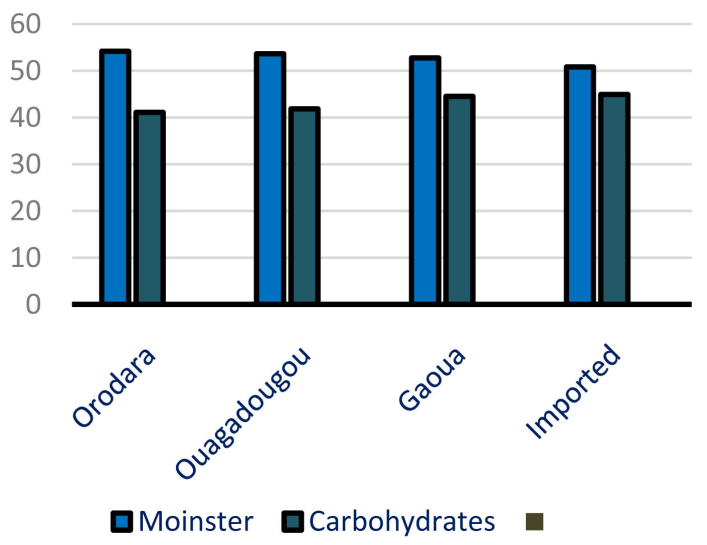

Figure 5. Additive values of attiéké biochemical properties.

to the dry matter (DM). Attiéké is then essentially an energizer food. The proteins content in attiéké varies from 0.77 to $1.74 \pm 0.13 \mathrm{~g}$ for $100 \mathrm{~g}$ and from $1.6 \pm 0.02$ to $3.78 \pm 0.27 \mathrm{~g} / 100 \mathrm{~g}$ according to the dry matter (Figure 4). Lipids content in attiéké analyzed varies from $0.15 \pm 0.01$ to $3.28 \pm 0.31 \mathrm{~g} / 100 \mathrm{~g}$. According to the dry matter, it is from $0.33 \pm 0.02$ to $7.16 \% \pm 0.62 \%$ (Figure 4). Total ashes of attiéké vary from 140 to $780 \pm 20 \mathrm{mg} / 100 \mathrm{~g}$ attiéké. In relation to the dry matter, ashes rate varies from $310 \pm 10$ to $1610 \pm 40 \mathrm{mg} / 100 \mathrm{~g}$ (Figure 4). The energizing values of the attiéké vary from 156.46 to $215.26 \mathrm{Kcal} / 100 \mathrm{~g}$. Attiéké is an energizing food which content in protein and lipids is weak.

\subsection{Mineral Contents in Attiéké}

The minerals content of attiéké in relation with the dry matter are: phosphorus, from 150 to $524 \mathrm{mg} / 100 \mathrm{~g}$; potassium, from 120 to $445 \mathrm{mg} / 100 \mathrm{~g}$; sodium from 217 to $885 \mathrm{mg} / 100 \mathrm{~g}$; calcium, from 42 to $116 \mathrm{mg} / 100 \mathrm{~g}$; magnesium, from 15 to $42 \mathrm{mg} / 100 \mathrm{~g}$; iron, from 7.05 to $14.29 \mathrm{mg} / 100 \mathrm{~g}$ and zinc, from 0.18 to $0.73 \mathrm{mg} / 100 \mathrm{~g}$ as shows in Table 2.

\subsection{Aflatoxins and Ochratoxin a Contamination}

Any attiéké sample tested reveals a contamination with aflatoxin $\left(B_{1}, B_{2}, G_{1}\right.$, and $\left.G 2\right)$ or with ochratoxin A. Then, either this food has not been contaminated by the toxigenic microorganisms or attiéké analyzed have some properties which do not hallow the growth of those microorganisms.

\section{Discussion}

\subsection{Chemical and Physicals and Microbiological Properties of Cassava Dough and Attiéké}

The imported cassava fermented dough has generally the highest content in acidity. This could be explained by the species of microorganisms associate in cassava dough fermentation [9]. There is a significant difference of cassava fermented dough acidity among producers and also from one production to another. And, according to the nature of the inoculum used, there is also a significant difference of the cassava dough acidity and it microbial charge.

The major part of sample has similar values of acidity to the Côte d'Ivoire norm for attiéké [21]. Sotomey [20] had found for the Beninese's attiéké, an acidity rate of $2.12 \pm 0.21$ and a $\mathrm{pH}$ of $5.03 \pm 0.24$. The difference of acidity among producers and productions observed could be explained by fermentation process mastery, transportation and storage conditions and also the nature of the inoculum [6] [22] [23]. Traoré [24] also proved that cassava variety influence it acidity value. The low acidity value of the bad cassava dough is in correlation with its weak load of fermented microorganisms. Acidity then mainly depends on fermentation process. The producers regulate the acidity of cassava dough to have acceptable value of attiéké acidity. The cassava dough acidity is then evaluated by tasting. This subjective evaluation is also changing from one day to another.

The impurities (organic and inorganic) constitute the third choice criteria of attiéké according to the consumers. Its frequency rate is about 36.9\% [25]. Diancoumba and Sawadogo [26] identified peeling and washing as 
Table 2. Minerals content of imported and local attiéké (mg/100g).

\begin{tabular}{|c|c|c|c|c|c|c|c|}
\hline & \multicolumn{5}{|c|}{ Attiéké from local fermented cassava dough } & \multicolumn{2}{|c|}{ Attiéké from imported cassava dough } \\
\hline & Soaked $^{\mathrm{a}}$ & Roasted $^{\mathrm{a}}$ & Blanched $^{\mathrm{a}}$ & Roasted $^{\mathrm{b}}$ & Soaked $^{\mathrm{c}}$ & Imported $^{1}$ & Imported $^{2}$ \\
\hline Phosphorus (P) & 329 & 509 & 524 & 150 & 748 & 254 & 194 \\
\hline Potassium (K) & 265 & 377 & 360 & 120 & 445 & 223 & 154 \\
\hline Calcium (Ca) & 86 & 82 & 95 & 42 & 116 & 48 & 54 \\
\hline Magnésium (Mg) & 30 & 34 & 36 & 15 & 42 & 20 & 23 \\
\hline Sodium (Na) & 440 & 641 & 567 & 217 & 885 & 355 & 238 \\
\hline Iron (Fe) & 7.93 & 7.05 & 12.36 & 7.17 & 8.96 & 11.85 & 14.29 \\
\hline Zinc (Zn) & 0.73 & 0.18 & 0.31 & 0.29 & 0.62 & 0.52 & 0.59 \\
\hline
\end{tabular}

${ }^{\mathrm{a}}$ : local sample from Ouagadougou; ${ }^{\mathrm{b}}$ : local sample from Orodara; ${ }^{\mathrm{c}}$ : local sample from Gaoua.

well as the burying underground of cassava dough as being the main process operation that govern the impurities rate. Indeed, during the peeling of the roots, the producers don't remove the central cylinder like Benin's producers [20] which increase the organic impurities value. The weak value of inorganic impurities showed an important reduction comparatively to previous results [27]. Sotomey [20] found a similar value in average and the Côte d'Ivoire norm recommends some values ranged from 75\% to 85\%. Microorganisms counts of this study are less than those of the previous works [9] [11] [28].

\subsection{Attiéké Nutritional Values}

Starch is the main component of the total carbohydrates of attiéké. It is an energizing food which had to be balanced with other foods [29]. Sahoré and Nemlin [30] found content in proteins of $1.75 \% \pm 0.01 \%$ and $1.70 \% \pm$ $0.00 \%$ respectively from soft and bitter cassava variety, and the Côte d'Ivoire norm defines a value of $1 \%$ to $2 \%$ as the normal protein rate according to the dry matter. Sotomey [20] had found protein content of $1.87 \% \pm 0.23 \%$ according to the dry matter. The weak value of protein content in attiéké is firstly due to the weakness content of cassava in protein [31]-[33]. Many factors can explain the protein content of attiéké: the variety of cassava used [30], soil composition, cultural technics and the process as well. The increase of proteins content in attiéké therefore depends on yeasts (unicellular protein organism) in cassava dough [34] [35]. Djoulde et al. [34] demonstrated that Lactobacillus plantarum and Rhizopus oryzaeuse as starter contribute to increase about $10 \% \pm 2 \%$ of protein content comparatively with the traditional fermentation method.

The content in lipids of attiéké is low and contributes a little to attiéké energizing value. Sotomey [20] has found lipids content of $0.8 \pm 0.09 \mathrm{~g} / 100 \mathrm{~g}$ in attiéké in relation to the dry matter. And, Sahoré and Nemlin [30] found lipids content of $1.25 \% \pm 0.03 \%$ from soft cassava variety attiéké and $1.40 \pm 0.05 \mathrm{~g} / 100 \mathrm{~g}$ from bitter cassava attiéké. Attiéké color and gluing factor depends on the nature and the quantity of oil added during the transformation process. About $0.5 \mathrm{l}$ of oil is added for $55 \mathrm{Kg}$ of cassava dough. The highest content in lipids of attiéké analyzed is 22 times higher than the lowest one.

Thus, attiéké macronutrients values showed an important variation which does not facilitate a proper estimation of its daily contribution to human body needs. The fluctuation of the average values is as shown in the following figure (Figure 8).

The ashes values found are similar to those of Sotomey [20] who had found on average, ashes content of 0.68 $\pm 0.09 \mathrm{~g} / 100 \mathrm{~g}$. The Côte d'Ivoire norm [21] requires ashes values less than $1.4 \mathrm{~g} / 100 \mathrm{~g}$ of dry matter. Total mineral salts content of attiéké is appreciable. There is an interrelationship between the content in ashes and the origin of the attiéké (cassava). So, on average, the attiéké of Gaoua has the strongest content $(0.77 \pm 0.01 \mathrm{~g} / 100 \mathrm{~g})$ followed by those of Ouagadougou $(0.47 \pm 0.1 \mathrm{~g} / 100 \mathrm{~g})$ and then, the imported one $(0.32 \pm 0.00 \mathrm{~g} / 100 \mathrm{~g})$ and lastly, the attiéké of Orodara $(0.2 \pm 0.03 \mathrm{~g} / 100 \mathrm{~g})$. Those results could be explained by cassava variety used for attiéké production or soil content in mineral in the regions where cassava in cultivated. Processing also influences ashes content in attiéké. In fact, Ouagadougou producers used the same variety of cassava for their production but they do not have the same value of ashes content. Favier [36], Diallo et al. [7] already put out the 
impact of processing on the nourishing value of the final product. According to Favier [36] the peeling operation unit only could cause the loss of $37 \%$ of cassava ashes.

The analyzed attiéké samples contained neither ochratoxins nor aflatoxins. Yandju et al. [37], found toxigenic moulds involved in the softening of cassava roots during low-moisture fermentation. But, Kastner et al. [41] did not found any contamination of aflatoxins among Côte d'Ivoire traditional inoculum. Only trace amounts of up to $0.2 \mathrm{mg} / \mathrm{kg}$ ochratoxins were present in some samples. The main toxigenic moulds are A. parasiticus, A. flavus,A. ochraceus, A. carbonarius,P. verrucosum, P. nordicum [39]-[41].

\subsection{Impact of Transformation Process on Attiéké Contents}

The processes influence significantly attiéké major components. The washing process influences starch and then carbohydrates content of attiéké. Sahoré and Nemlin [30] had found a variation of 13\% on the total carbohydrates content according to the process. In average, the content in proteins of the attiéké produced in Ouagadougou is relatively higher than both the imported one and the one from Gaoua and Orodara. And, besides Ouagadougou producers who use the same cassava variety there is an important variation of the protein content in cassava (Figure 6).

This fluctuation is also observed with the imported dough attiéké. The variation among producers (Figure 6) and from one production to another (Figure 7), points out the impact of the processing on protein content in attiéké. Sahoré and Nemlin [30] showed that from the raw material to the final product (attiéké), the reduction of the content in protein is about 3 to $5 \%$.

As showed in Figure 8 it appears that any producer manages to maintain a steady value of lipids content in attiéké from one production to another. The content in lipids increases the energizing value of attiéké but also presents a risk of degradation of the nutritional value during the storage. There is an important variation of moister also among producers and from one production to another. The mainly processing that influence attiéké content in moister are pressing, drying and cooking. This fluctuation is due to the fact that the processing is still traditional [40].

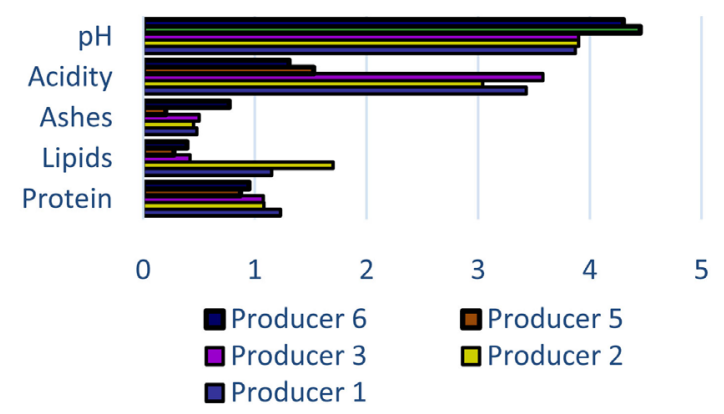

Figure 6. Variation of biochemescal parameters according to producers.

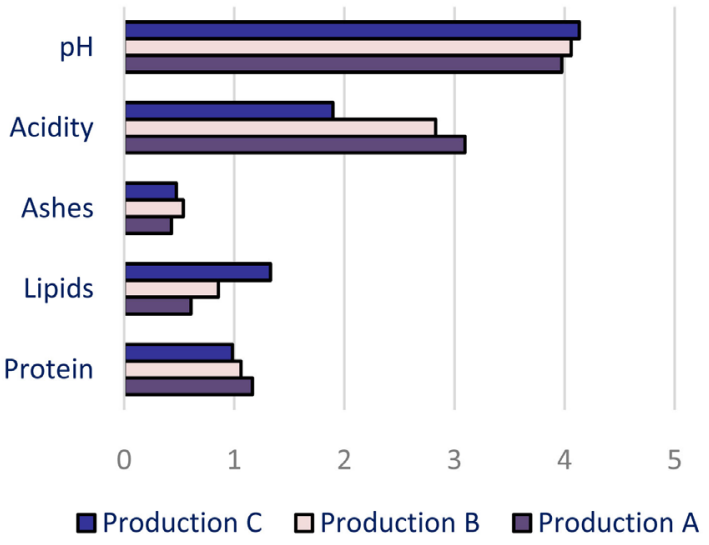

Figure 7. Variation of the biochemical parameters according to productions. 


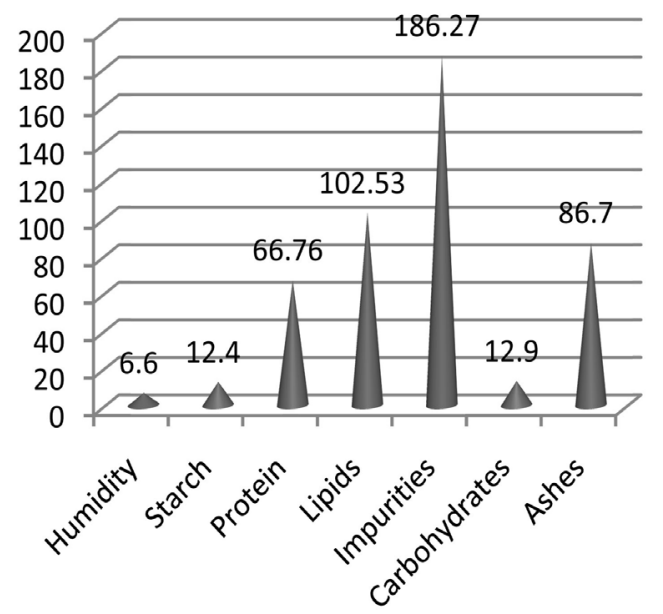

Figure 8. Coefficient of variation (\%) of seven parameters in attiéké.

Many productions process influence attiéké component and therefore its nutritional value. According to the coefficient of variation, the parameters that are influenced the most by processes are impurities, lipids, ashes, protein, starch and carbohydrates as it is showed in the following picture (Figure 8).

\section{Conclusions}

The load of microorganisms associated in fermentation (lactic bacteria, yeasts and mildews) and the acidity of cassava dough are more important in local products than in the imported one. Local attiéké also has higher values in proteins and minerals salt. Attiéké is essentially an energizing food with a weak value of protein, and lipids. Attiéké chemical and physical components and the species of microorganisms involved in its fermentation did not allow the development of toxigenic microorganisms which produced ochratoxin or aflatoxin.

The variation of attiéké contents is tribute to processing, cassava variety (protein, carbohydrates, and minerals salt) soil content in minerals as well as farmers' practices (protein, minerals salt, carbohydrates). Production process influences the content in starch and in total carbohydrates (peeling and washing), proteins (nature, quantity of inoculum and time of fermentation), acidity (washing, kind and quantity of inoculum and time of fermentation), lipids (oil addition), total minerals salt (peelings), and in impurities rate (good practices of production).

\section{Acknowledgements}

The financial support of PDA/GIZ as well as the DTA/IRSAT technicians and all attiéké producers involved contribution are gratefully acknowledged.

\section{References}

[1] Padmaja, G. and Steinkraus, K.H. (1995) Cyanide Detoxification in Cassava for Food and Feed Uses. Critical Reviews in Food Science and Nutrition, 35, 299-329. http://dx.doi.org/10.1080/10408399509527703

[2] Diabcoumba, D. (2008) Diagnostic actualisé de la filière manioc pour une analyse de chaines de valeur (CVA). PDA, p. 25.

[3] Amoa-Awua, W.K.A., Appoh, F.E. and Jakoben, M. (1996) Lactic Acid Fermentation of Cassava Dough into Agbelima. International Journal of Food Microbiology, 31, 87-98. http://dx.doi.org/10.1016/0168-1605(96)00967-1

[4] Kuye, A. and Sanni, L.O. (1999) Industrialisation of Fermented Food Processes: How Far in Nigeria. Journal of Scientic and Industrial Research, 58, 837-843.

[5] Coulin, P., Farah, Z., Assanvo, J., Spillmann, H. and Puhan, Z. (2006) Characterisation of the Microflora of Attiéké, a Fermented Cassava Product, during Traditional Small-Scale Preparation. International Journal of Food Microbiology, 106, 131-136. http://dx.doi.org/10.1016/j.ijfoodmicro.2005.06.012

[6] Nimage, D., Achille, T.F., Abodjo, K.C., Charlemagne, N. and Georges, A.N. (2012) Influence of Traditional Inoculum and Fermentation Time on the Organoleptic Quality of “Attiéké”. Food and Nutrition Sciences, 3, 1335-1339. http://dx.doi.org/10.4236/fns.2012.310176 
[7] Younoussa, D., et al. (2013) Importance nutritioneelle du manioc et perspectiveves pour l'alimentation de base au Sénégal (synthèse bibliographique). Biotechnologie, Agronomie, Société et Environnement, 17, 634-643.

[8] Soro-Yao, A.A., Brou, K., Koffi-Nevry, R. and Djè, K.M. (2013) Microbiology of Ivorian Fermented Products: A Review. Asian Journal of Agriculture and Food Science, 1, 37-47.

[9] Assanvo, J.B., Agbo, G.N., Behi, Y.E.N., Coulin, P. and Farah, Z. (2002) La microflore du ferment de manioc pour la production de l'attiéké adjoukrou à Dabou (Côte d’Ivoire). Bioterre, rev.inter sci. et de la terre., No. Spéciale, 286299.

[10] Kastner, S. (2008) The Inoculum of the Cassava Product Attiéké: Microbiological Diversity, Impact on Product Quality and Safety, and Development of a Controlled Fermentation Process. Mémoire de these, ETH ZURICH, p. 155.

[11] Djeni, N.T., et al. (2015) Biochemical and Microbial Characterization of Cassava Inoculum from the Three Main Attieke Production Zones in Côte d'Ivoire. Food Control, 50, 133-140. http://dx.doi.org/10.1016/j.foodcont.2014.08.046

[12] (1999) ISO-6887. 1. Microbiologie des aliments-Préparation des échantillons, de la suspension mère et des dilutions décimales en vue de l'examen microbiologique. Partie 1: Règles générales pour la préparation de la suspension mère et des dilutions décimales. p. 5.

[13] (1988) ISO-7954. Directives générales pour le dénombrement des levures et moisissures, techniques par comptage des colonies à $25^{\circ} \mathrm{C}$. p. 4.

[14] (1998) ISO-15214. Microbiology of Food and Animal Feeding Stuffs_-Horizontal Method for the Enumeration of Mesophilic Lactic Acid Bacteria-Colony Count Technique at $30^{\circ}$ C. p. 5.

[15] American Oil Chemists Society (AOCS) (1990) Official Methods and Recommanded Pratics. 4. s.l. AOCS, Urbana, 322-340.

[16] Toiller, M. and Robin, J.P. (1979) Adaptation of the Sulfuric Orcinol Method to Automatic Proportioning of the Neutral Totals Sugars: Conditions for Application to the Vegetable Extracts. Annales de Technologie Agricole, 28, 1-15.

[17] Jarvis, S.C., and Walker, F.R.L. (1993) Simultaneous, Rapid, Pectrophotometric, Determination of Total Starch, Amylose and Amylopectin. Journal of the Science of Food and Agriculture, 63, 53-57. http://dx.doi.org/10.1002/jsfa.2740630109

[18] Merill, A.L. and Watt, B.K. (1975) Energy Value of Foods Basis and Derivation. In: Agricultural Handbook No. 74, US Government Printing Office, Washington DC, 105.

[19] ISO-16050 (2003) Dosages des aflatoxines B1 détermination de la teneur totale en aflatoxines B1, B2, G1, G2 dans les céréales, les fruits à coque las produits dérivés-Méthode par chromatographie liquide à haute performance.

[20] Sotomey, M. and Eric-Alain, D. (2001) Innovation Diffision de Produits Alimentaires en Afrique: l’attiéké au Bénin. CIRAD, 98.

[21] CODINORM (2006) Attiéké-Spécifications. NI4511 Côte d'Ivoire, Norme.

[22] Perez, J.M., et al. (1981) Valeur énergétique de deux types de manioc utilisation comparée dans les régimes du porc en croissance du porcelet: synthèse des résultats d'une étude concertée. INRA, ITP, 125-144.

[23] Tetchi, F.A., et al. (2012) Effect of Cassava Variety and Fermentation Time on Biochemical and Microbiological Characteristics of Raw Artisanal Starter for Attiéké Production. Innovative Romanian Food Biotechnology, 10, 40-47.

[24] Traoré, A. (2008) Test d'aptitude technologique de cinq variétés de manioc en attiéké. s. l. PDA, 25.

[25] Poukou, K. (2006) Analyse économique de la demande des traits caractéristiques des produits dérivés de manioc en milieux urbains de Côte d’Ivoire: cas de l'éttiéké. CIRES, 19.

[26] Diancoumba, D. and Sawadogo, L.H. (2010) Etude pour une analyse sommaire des risques pour la qualité dans la CVA manioc promue par le PDA. s. l. PDA, 58.

[27] Bassolé, I.H.N. (2009) Evaluation des acquis des formations en Bonnes pratiques d'Hygiène (BPH) au profit des transformations de manioc en attiéké, session de. s. l. PDA, 2011, 47.

[28] Wakil, S.M. and Ajayi, O.O. (2013) Production of Lactic acid from Stacrchy-Based Subtrates. Journal of Applied Biosciences, 71, 5673-5681. http://dx.doi.org/10.4314/jab.v71i1.98811

[29] Amani, G.N. and Kamenen, A. (2003) Potentialité nutritionnelles technologie traditionnelle de transformation des denrées amylacées en Côte d'Ivoire. 123-132.

[30] Sahoré, D.A. and Nemlin, G.J. (2010) Effect of Technological Treatments on Cassava (Manihot esculenta Crantz). Food and Nutrition Sciences, 1, 19-23. http://dx.doi.org/10.4236/fns.2010.11004

[31] Bergeret, B., et al. (1957) Tables de Composition de quelques Aliments Tropicaux. Anales de la Nutrition de l'alimentation, 5, 15.

[32] Oyewole, O.B. and Asagbra, Y. (2003) Improving Traditional Cassava Processing for Nutritional Enhancement. 2nd 
International Workshop: Voies Alimentaires d'amélioration des Situations Nutritionnelles, Ouagadougou, 23-28 Novembre 2003, 123-127.

[33] Heuberger, C. (2005) Cyanide Content of Cassava and Fermented Products with Focus on Attieke and Attieke Garba. Diss Eth No. 16247, 21.

[34] Djoulde, D.R., Francois-Xavier, E., Jean-Justin, E.N. and Carl, M.M.F. (2003) Fermentation du manioc cyanogène par une culture mixte de lactobacillus plantarum et Rhizopus oryzae. Microbiology Hygiene Ali, 15, 9-13.

[35] Ouédrago, N. Éd. (2010) Valorisation des déchets de tubercules (patate douce igname) par la production de protéines d’intérêts. Mémoire de DEA. s. l., Université de Ouagadougou, Ouagadougou, 95.

[36] Favier, J.C. (1977) Valeur Alimentaire de deux aliments de Base Africains: le manioc le sorgho. ORSTOM, 127.

[37] Yandju, D.L., Matondo, K.L. and Munyanganizi, B. (1995) Les moisissures toxinogènes impliquées dans le ramolissement des racines tubéreuses du manioc en fermentation sèche. ORSTOM, 368-373.

[38] Belkacem, N. éd. (2008) Les mycoyoxines:production voie de biosynthèse. Mémoire de Master 2. s. l., Institut National Polytechniques de Toulouse.

[39] Kumulungui, B.S., Ondo-Azi, A.S., Madinda, N.F. and Mouaragadja, I. (2012) Isolement des microorganismes impliqués dans la pourriture des racines tubereuses du manioc (Manihot esculenta CRANTZ) au Gabon. Agronomie Africaine, 24, 171-181.

[40] Dédédji, M.M., Ahouansou, R. and Hounhouigan, D.J. (2008) Evaluation des preformances techniques d'un granuleur mécanique pour la production d'attiéké (couscous de manioc) au Bénin. Bulletin de la recherche agronomique du Bénin, No. 61, 37.

[41] Sabine, K., Kandlerb, H., Hotzb, K., Bleischb, M., Lacroixa, C. and Meilea, L. (2010) Screening for Mycotoxins in the Inoculum Used for Production of Attiéké, a Traditional Ivorian Cassava Product. LWT-Food Science and Technology, 43, 1160-1163. http://dx.doi.org/10.1016/j.lwt.2010.01.023 